Т. О. Петрушанко, Е. В. Ніколішина, Н. М. Іленко, І. Ю. Попович, І. Ю. Литовченко

Вищий державний навчальний заклад Украӥни “Украӥнська медична стоматологічна академія”, м. Полтава

\title{
ДОСВІД ПОЗААУДИТОРНОЇ РОБОТИ ЗІ СТУДЕНТАМИ НА КАФЕДРІ ТЕРАПЕВТИЧНОЇ СТОМАТОЛОГІЇ
}

\author{
T. O. Petrushanko, E. V. Nikolishyna, N. M. Ilenko, I. Yu. Popovich, \\ I. Yu. Litovchenko \\ Ukrainian Medical Stomatology Academy, Poltava

\section{EXPERIENCE OF OUT-OF-CLASS WORK WITH STUDENTS AT THE THERAPEUTIC STOMATOLOGY DEPARTMENT}

\begin{abstract}
Мета роботи - проаналізувати сутність позааудиторної самостійної роботи студентів як складової професійної підготовки майбутніх лікарів-стоматологів, а також висвітлити досвід ії організації та проведення на кафедрі терапевтичної стоматології ВДНЗУ “УМСА”.

Основна частина. Для підвищення освітнього рівня підготовки висококваліфікованих спеціалістів та збагачення їх інтелектуального та творчого потенціалу слід постійно раціоналізовувати навчальний процес шляхом удосконалювання змісту, форм і методів навчально-пізнавальної діяльності студентів вищих навчальних закладів. При обмеженні навчального аудиторного часу виникає необхідність навчання в позааудиторний час. Заходами позааудиторної роботи з розвитку особистості майбутнього лікаря і підготовки професійно-орієнтованого фахівця є проведення відбіркового туру Всеукраїнського студентського конкурсу на кращу практичну роботу “Фахівець”, а також індивідуальні та групові фантомні заняття.

Висновок. Практично спрямований вид позааудиторної роботи дозволяє кожному бажаючому студенту напрацювати мануальні навички, сприяє максимальному розвитку індивідуальних творчих здібностей і в кінцевому підсумку приводить до поліпшення якості та рівня підготовки майбутніх фахівців.
\end{abstract}

Ключові слова: практичні навички; позааудиторна робота.

The aim of the work - to analyze the essence of the student's independent work as an integral part of the professional training of future dentists, and also to highlight the experience of its organization and carrying out at the Department of Therapeutic Dentistry of the Ukrainian Medical Stomatology Academy.

The main body. To improve the educational level of training highly qualified specialists and rise up their intellectual and creative potential, the educational process should be constantly rationalized by enchanced the content, forms and methods of educational and cognitive activity of students of higher educational institutions. With the restriction of classroom time, there is a need for training in out-of-class work. Measures of out-of-class work on the development of the personality of the future doctor and the training of a professional-oriented specialist are the selection of conduct of Ukrainian student competition for the best practical work "Specialist", as well as individual and group phantom studies.

Conclusion. Practically oriented type of out-of-class work allows each student to develop manual skills, promotes the maximum development of individual creative abilities and finally leads to improving the quality and level of training of future specialists.

Key worlds: practical skills; out-of-class work.

Вступ. На сучасному етапі прискореного соціально-економічного розвитку суспільства, що характеризується поступовою й неухильною інтеграцією України в європейські політичні, економічні та культурні структури, важливого значення набуває підвищення освітнього рівня підготовки висококваліфікованих спеціалістів і збагачення їх інтелектуального та творчого потенціалу [1, 2].

(C) Т. О. Петрушанко, Е. В. Ніколішина, Н. М. Іленко та ін.
Для цього слід постійно раціоналізовувати навчальний процес шляхом удосконалювання змісту, форм і методів навчально-пізнавальної діяльності студентів вищих навчальних закладів, що якнайкраще розвивало і формувало б їх творчі здібності [3]. При обмеженні навчального аудиторного часу, а також з урахуванням психологічних особливостей студента, виникає необхідність навчання в позааудиторний час [3]. 
Незважаючи на тісний зв'язок з аудиторною роботою, позааудиторна робота має свої відмінності, а саме: участь студентів у позааудиторній роботі добровільна, а на навчальному занятті - обов’язкова; позааудиторні заходи мають невимушений характер і тому надають більші можливості для прояву самостійності студентів, їхньої ініціативності та творчості.

Професійна підготовка майбутнього лікаря-стоматолога базується на глибоких теоретичних знаннях у поєднанні з високими мануальними навичками. Розвиток творчого потенціалу вмотивованої особистості вимагає, щоб у процесі навчання поряд 3 когнітивним процесом більше уваги було приділено розвитку мануальних навичок, а також морально-вольової сфери з повною свободою рішень, дій та самооцінки майбутнього стоматолога [2].

Величезне значення у формуванні даних навичок має рання мотивація студентів, яка формується під час індивідуальної або колективної діяльності, під керівництвом, але без безпосередньої участі викладача в спеціально відведений для цього аудиторний або позааудиторний час [4].

Під час аудиторної роботи відбувається традиційне засвоєння основної освітньої програми згідно з навчально-тематичними планами, шляхом відвідування практичних занять, лекцій, семінарів тощо. Останнім часом у зв'язку зі зниженням аудиторного навантаження все більше академічних годин відводиться на індивідуальну роботу студентів у позааудиторний час, у тому числі і під керівництвом викладача [5].

Мета роботи - аналіз сутності позааудиторної самостійної роботи студентів на кафедрі терапевтичної стоматології ВДНЗУ “УМСА” як складової професійної підготовки майбутніх лікарів-стоматологів.

Основна частина. Такими заходами позааудиторної роботи з розвитку особистості майбутнього лікаря і підготовки професійно-орієнтованого фахівця на кафедрі терапевтичної стоматології ВДНЗУ “УМСА” $є$ проведення відбіркового туру Всеукраїнського студентського конкурсу на кращу практичну роботу “Фахівець”, а також індивідуальні та групові фантомні заняття $[4,5]$.

Співробітники кафедри терапевтичної стоматології понад п'ятнадцять років організовують і проводять конкурс професійної майстерності серед студентів-старшокурсників, який є вузівським туром Всеукраїнського конкурсу на кращу студентську практичну роботу. Всеукраїнський конкурс
“Фахівець” з 2002 р. проводився у Львові, його ініціювала заслужений діяч науки і техніки України, доктор медичних наук Ніна Іванівна Смоляр. В останні роки конкурс проводився на базі ДВНЗ “Тернопільський державний медичний університет імені І. Я. Горбачевського МОЗ України”. В ході конкурсу студентам надається можливість провести препарування двох каріозних порожнин фронтальної групи зубів, виконати реставрації в чотири руки і відновити дефекти композитним матеріалом світлового затвердіння за дві з половиною години.

Оцінюються конкурсні роботи студентів кваліфікованим журі за загальноприйнятими міжнародними параметрами, такими, як: вміння працювати 3 асистентом в чотири руки; правильність виконання техніки знеболювання; завершеність етапу препарування каріозної порожнини; правильність використання додаткових пристосувань (кофердама, матриць і т. д.); реставрація оцінюється по підбору кольору, відновленню анатомічної форми зуба, крайовому приляганню, якості фінішної обробки, наявності контактного пункту.

Фотофіксація вихідної ситуації, окремих етапів роботи та отриманого результату дозволяє членам журі детально розглянути кожний клінічний випадок й обрати гідного переможця конкурсу. Фотозвіт реставраційних робіт виставляється на сайті кафедри, що дає змогу для обговорення, коментування та оцінювання широкій незалежній аудиторії користувачів Інтернету.

Цікавим моментом конкурсу є аналіз помилок. На моніторі комп'ютера кожен конкурсант має можливість побачити свою роботу на різних етапах виконання, вислухати зауваження, поради членів журі, оцінити її самостійно, порівняти з роботою інших конкурсантів.

Переможець вузівського етапу реставраційного конкурсу отримує можливість на додаткову, позаурочну, індивідуальну роботу з консультантами викладачами кафедри терапевтичної стоматології по вдосконаленню практичних навичок з реставрації зубів. А також право представляти академію на заключному етапі Всеукраїнського студентського конкурсу на кращу практичну роботу.

Студенти нашої академії завжди гідно представляли рідну Альма-матер у Львові та Тернополі. За 15 років існування Всеукраїнського конкурсу “Фахівець” вихованці кафедри терапевтичної стоматології завойовували найпрестижніші перші (Ірина Остапченко, 2003 р., Григорій Туркот, 2006 р., Андрій Климко, 2007 р.), другі (Іван Попович, 2003 р., 
Мирослав Лоза, 2005 р., Костянтин Костишин, 2008 р., Дмитро Удовченко, 2011 р., Борис Свінціцький, 2012 р., Денис Крамаренко, 2014 р., Валентин Яковішен, 2015 р., Марія Василенко, 2016 р.) і треті місця (Лариса Петрушенко, 2013 р.).

Протягом останніх п’яти років найбільш популярним серед широкої аудиторії студентів заходом позааудиторної роботи на кафедрі терапевтичної стоматології $\epsilon$ індивідуальні та групові фантомні заняття, які співробітники кафедри проводять у позаурочний час. 3 метою матеріального забезпечення конкурсу та фантомних занять кафедра тісно співпрацює з фірмою Dentsplay Sirona, яка надає студентам унікальну можливість підвищувати свої мануальні навички при роботі з сучасними матеріалами.

На фантомних заняттях, які проходять у невимушеній обстановці, невеличкими групами до 10 осіб, студенти протягом першої частини поглиблено розбирають сучасні теоретичні аспекти теми, під час другої частини напрацьовують свої мануальні навички під безпосереднім керівництвом викладача.

Тематика фантомних занять охоплює всі напрямки сучасної терапевтичної стоматології, такі, як: пряма реставрація фронтальних та бокових зубів,

\section{Список літератури}

1. Тенденції інтеграції систем підготовки та атестації медичних кадрів у світі та Україні / Ю. В. Вороненко, Ю. П. Вдовиченко, О. К. Толстанов [та ін.] // Реалізація Закону України “Про вищу освіту” у вищій медичній та фармацевтичній освіті України : матеріали Всеукр. навч.-наук. конф. з міжнар. участю. - Тернопіль, 2016. C. 25-28.

2. Булах І. Є. Проблеми оцінювання знань студентів у контексті вимог Болонської декларації / І. Є. Булах, О. П. Волосовець, М. Р. Мруга // Медична освіта. - 2011. № 2. - C. 20-22.

3. Ждан В. М. Досвід упровадження нових форм організації навчального процесу в умовах кредитно-модульної системи / В. М. Ждан, В. М. Бобирьов,

\section{References}

1. Voronenko, Iu.V., Vdovychenko, Iu.P., Tolstanov, O.K., Mintser, O.P., \& Krasnov, V.V. (2016). Tendentsii intehratsii system pidhotovky ta atestatsii medychnykh kadriv u sviti ta Ukraini [Trends in the integration of training and certification systems for medical personnel in the world and in Ukraine]. Realizatsiia zakonu Ukrainy «Pro vyshchu osvitu» $u$ vyshchyi medychnii ta farmatsevtychnii osviti Ukrainy: Vseukrainska navchalno-naukova konferentsiia z mizhnarodnoiu uchastiu: Mat. konf. - Implementation of the Law відбудова контактного пункту, різні види адгезивних технологій (шинування, виготовлення мостів, штифтових зубів), ручна та машинна ендодонтія, вибілювання зубів, сучасна пародонтологія, професійна гігієна та інші.

Кожен студент самостійно виконує певні навички на фантомах, отримує індивідуальну консультацію висококваліфікованого фахівця на кожному етапі роботи, має можливість порівняти свої досягнення з роботою інших студентів, об'єктивно оцінити власні здібності та творчі можливості.

Під час такої позаурочної роботи, коли відвідування заняття залежить саме від бажання студента, формується необхідність постійного поновлення знань, самовдосконалення, самодисципліна та самоконтроль.

Висновок. Враховуючи багаторічний досвід роботи кафедри терапевтичної стоматології в даному напрямку, вважаємо, що саме практично спрямований вид позааудиторної роботи дозволяє кожному бажаючому студенту напрацювати мануальні навички, сприяє максимальному розвитку індивідуальних творчих здібностей і в кінцевому підсумку приводить до поліпшення якості та рівня підготовки майбутніх фахівців.

О. В. Шешукова // Інтеграція української медичної освіти в європейський та американський медичний простір : матеріали навч.-наук. конф. - Тернопіль, 2006. С. 34-35.

4. Шляхи вдосконалення практичних навичок із терапевтичної стоматологї / Н. М. Іленко, А. В. Марченко, Е. В. Ніколішина, Н. В. Іленко // Основні напрямки удосконалення підготовки медичних кадрів у сучасних умовах : матеріали Всеукр. навч.-наук. конф. з міжнар. участю. - Полтава, 2015. - С. 99-100.

5. Петрушанко Т. О. Значення фантомних занять у формуванні практичних навичок майбутніх лікарівстоматологів / Т. О. Петрушанко, Л. Й. Островська, I. Ю. Попович // Український стоматологічний альманах. - 2016. - № 1, т. 2. - С. 94-97.

of Ukraine "On Higher Education" in the Higher Medical and Pharmaceutical Education of Ukraine: All-Ukrainian Educational and Scientific Conference with International Participation: Proceedings of the Conference. Ternopil. 2016. (pp.25-28) [in Ukrainian].

2. Bulakh, I.Ie., Volosovets, O.P., Mruha, M.R. (2011). Problemy otsiniuvannia znan studentiv u konteksti vymoh Bolonskoi deklaratsii [Problems of assessment of students' knowledge in the context of the requirements of the 
Bologna Declaration]. Medychna osvita - Medical Education, (2), 20-22 [in Ukrainian].

3. Zhdan, V.M., Bobyrov, V.M., \& Sheshukova, O.V. (2006). Dosvid uprovadzhennia novykh form orhanizatsii navchalnoho protsesu v umovakh kredytno-modulnoi systemy [Experience of introduction of new forms of organization of educational process in conditions of credittransfer system]. Intehratsiia ukrainskoi medychnoi osvity $v$ yevropeiskyi ta amerykanskyi medychnyi prostir: Navchalnonaukova konferentsiia: Mat. konf. - Integration of Ukrainian medical education into European and American medical space: Proceedings of the Conference. Ternopil, 2006. (pp.34-35) [in Ukrainian].

4. Ilenko, N.M., Marchenko, A.V., Nikolishyna, E.V., \& Ilenko, N.V. (2015). Shliakhy vdoskonalennia praktychnykh navychok iz terapevtychnoi stomatolohii [Ways to improve practical skills in therapeutic dentistry]. Osnovni napriamky udoskonalennia pidhotovky medychnykh kadriv u suchasnykh umovakh: Vseukrainska navchalno-naukova konferentsiia z mizhnarodnoiu uchastiu: Mat. konf. - The main directions of improvement of training of medical personnel in modern conditions: Proceedings of the International Conference. Poltava, 2015. (pp. 99-100) [in Ukrainian].

5. Petrushanko, T.O., Ostrovska, L.I., Popovych, I.Iu. (2016). Znachennia fantomnykh zaniat u formuvanni praktychnykh navychok maibutnikh likariv-stomatolohiv [The significance of phantom lessons in shaping the practical skills of future dental practitioners]. Ukrainskyi stomatolohichnyi almanakh - Ukrainian Dental Almanac, 1 (2), 94-97 [in Ukrainian].

Отримано 15.11.17

Електронна адреса для листування: ellanikolishyna@gmail.com 